\title{
Turgida turgida (Nematoda: Physalopteridae) parasitic in white-bellied opossum, Didelphis albiventris (Marsupialia: Didelphidae), state of Mato Grosso do Sul, Brazil ${ }^{1}$
}

\author{
Roberta M.P. Humberg², Luiz Eduardo R. Tavares ${ }^{3}$, Fernando \\ Paiva $^{3}$, Elisa T. Oshiro ${ }^{3}$, Raquel A. Bonamigo ${ }^{4}$, Norton T. Júnior ${ }^{4}$ \\ and Alessandra G. Oliveira ${ }^{2,3^{*}}$
}

\begin{abstract}
Humberg R.M.P., Tavares L.E.R., Paiva F., Oshiro E.T., Bonamigo R.A., Júnior N.T. \& Oliveira A.G. 2011. Turgida turgida (Nematoda: Physalopteridae) parasitic in white-bellied opossum, Didelphis albiventris (Marsupialia: Didelphidae), state of Mato Grosso do Sul, Brazil. Pesquisa Veterinária Brasileira 31(1):78-80. Departamento de Patologia, Universidade Federal de Mato Grosso do Sul, Cx. Postal 549, Campo Grande, MS 79070-900, Brazil. E-mail: agoliveira@nin.ufms.br

Turgida turgida have been largely reported parasitizing Didelphis species in North and South America based on light microscopy observation. However, the features that differentiate T. turgida from other physalopterid species should be observed using scanning electron microscopy (SEM). A female white-bellied opossum, Didelphis albiventris, arrived dead at the Centro de Reabilitação de Animais Silvestres (CRAS) in the municipality of Campo Grande, state of Mato Grosso do Sul, Brazil. During the necropsy, adult nematodes were collected from stomach and intestine. The nematodes were determined to be adult specimens and submitted to SEM for the species determination. This is the first report of $T$. turgida confirmed by SEM in the Neotropical region and the first report in an urban area in the state of Mato Grosso do Sul, Brazil.
\end{abstract}

INDEX TERMS: Nematodes, Didelphis, Scanning Electronic Microscopy, Urban, Turgida.

RESUMO.- [Parasitismo por Turgida turgida (Nematoda: Psysalopteridae) em gambá de orelha branca, Didelphis albiventris (Marsupialia: Didelphidae), estado de Mato Grosso do Sul.] Turgida turgida tem sido amplamente relatada parasitando espécies de Didelphis na América do Norte e América do Sul com base em microscopia óptica. No entanto, as características que diferenciam $T$. turgida de outras espécies de Physalopteridae, devem ser observadas utilizando microscopia eletrônica de varredura (MEV). Uma fêmea, de gambá-de-orelha-branca, Didelphis albiventris, chegou morta no Centro de Reabilitação de

\footnotetext{
1 Received on June 25, 2010.

Accepted for publication on October 25, 2010

2 Programa de Pós-Graduação em Doenças Infecciosas e Parasitárias, Faculdade de Medicina Dr. Hélio Mandetta, Universidade Federal de Mato Grosso do Sul (UFMS), Cx. Postal 549, Campo Grande, MS 79070-900, Brazil.

${ }^{3}$ Departamento de Patologia, UFMS, Cx. Postal 549, Campo Grande, MS. *Corresponding author: agoliveira@ nin.ufms.br

${ }^{4}$ Curso de Graduação em Medicina, bolsista de Iniciação Científica CNPq (PIBIC 2008/09), Faculdade de Medicina Dr. Hélio Mandetta, UFMS, Campo Grande, MS 79070-900.
}

Animais Silvestres (CRAS) no município de Campo Grande, Estado de Mato Grosso do Sul, Brasil. Durante a necropsia, os nematóides adultos foram coletados do estômago e do intestino, identificados macroscopicamente e submetidos à MEV para a determinação específica. Este é o primeiro relato de $T$. turgida confirmado por MEV na região Neotropical, e o primeiro relato em uma área urbana no estado de Mato Grosso do Sul.

TERMOS DE INDEXAÇÃO: Nematóides, Didelphis, Microscopia Eletrônica de Varredura, urbano, Turgida.

\section{INTRODUCTION}

Turgida turgida (Rudolphi 1819) is a parasitic nematode belonging to the family Physalopteridae (Railliet 1893) that has several species of mammals as definitive hosts in which adults live attached to the stomach wall (Anderson 2000). Insects belonging to the orders Orthoptera and Coleoptera serve as intermediate hosts in which the larvae are encysted in the outer wall of intestine (Anderson 2000). Frequently, paratenic hosts such as reptiles and amphibians have also been reported (Widmer 1970). 
The different species of Physalopteridae seem to be selective to the infection site, occurring in the stomach region. Turgida turgida is normally found in the greater curvature of stomach, while Physaloptera maxilaris also inhabits the fundic region, $P$. hispida is found at the pylorus and $P$. praeputialis attaches itself to the small curvature of stomach (Zago Filho 1959, Anderson 2000).

Attaching to the gastric mucous and rarely to the intestinal mucous, the adult form of the nematode causes the development of enterogastric symptoms and stimulates the hypersecretion of mucus in the host (Levine 1980).

The white-bellied opossum, Didelphis albiventris (Lund 1840 ), is a small wild mammal with nocturnal habits. The species inhabits open, deciduous forests from northeastern Brazil to mid-Argentina and is commonly found in urban forest fragments. The white-bellied opossum is an opportunistic omnivore and feeds on a diversity of invertebrates and small vertebrates, which can play a role as intermediate or paratenic hosts of several helminth species (Cáceres 2000, Aléssio et al. 2005).

\section{MATERIALS AND METHODS}

A female white-bellied opossum, Didelphis albiventris, was run over and arrived dead at the Centro de Reabilitação de Animais Silvestres (CRAS) in the municipality of Campo Grande, state of Mato Grosso do Sul, Brazil. During necropsy, nematodes were found in the stomach and intestine, which were collected and separated for identification. A total of 15 nematodes were fixed in

Fig.1. SEM micrographs of adult specimens of Turgida turgida recovered from a white-bellied opossum, Didelphis albiventris, in an urban area in the state of Mato Grosso do Sul, Brazil. (A) Cephalic end, apical view, showing tripartite tooth, associated structures and crescent fold (black arrow). (B) Posterior end of male, ventral side, distribution of papillae and cloacal aperture with spicules. (C) Postcloacal papillae and broad truncated papilla (black arrow).

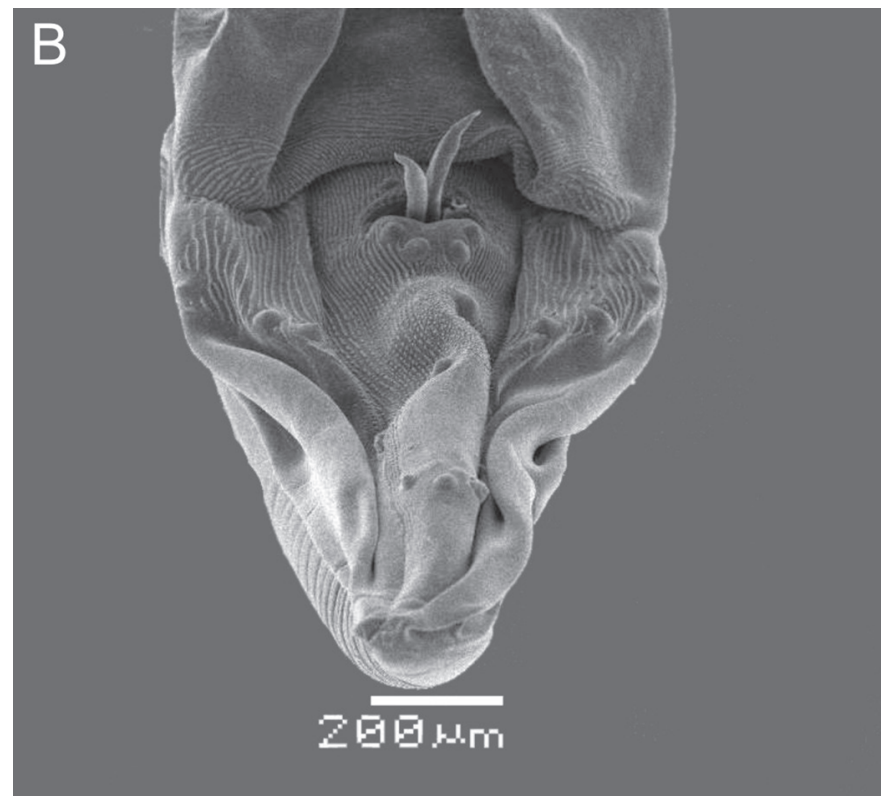

$10 \%$ formaldehyde solution and cleared in lactophenol for light microscopy. For the scanning electron microscopy (SEM) analysis, four specimens (one male and three females) were removed from the formaldehyde solution and rinsed with distilled water, fixed in a $2.5 \%$ glutaraldehyde and $2.0 \%$ paraformaldehyde solution for $24 \mathrm{~h}$ and postfixed in $1.0 \%$ osmium tetroxide; both solutions were prepared with a $0.05 \mathrm{M}$ sodium cacodylate buffer ( $\mathrm{pH}$ 7.2) and subsequently rinsed with the same buffer solution. After dehydration in an ethanol series, the specimens were critical-point dried with carbon dioxide, mounted on SEM stubs using a carbon adhesive tape, sputter-coated with gold in sputtering apparatus (Denton Desk III) and examined with a scanning electron microscope (JEOL JSM 6380LV) at $15 \mathrm{kV}$ and a working distance of $25 \mathrm{~mm}$. For the measurements $(\mathrm{mm})$, means are followed by range in parenthesis. Identification was carried out based on Matey et al. (2001).

\section{RESULTS}

The nematodes were male $(n=3)$ and female $(n=12)$ specimens of Turgida turgida, with a mean length of 24.75 (19.18-31.96) and 30.17 (17.84-48.46), respectively, and a maximal width of 1.63 (1.87-1.29) and 2.15 (1.28-2.86),
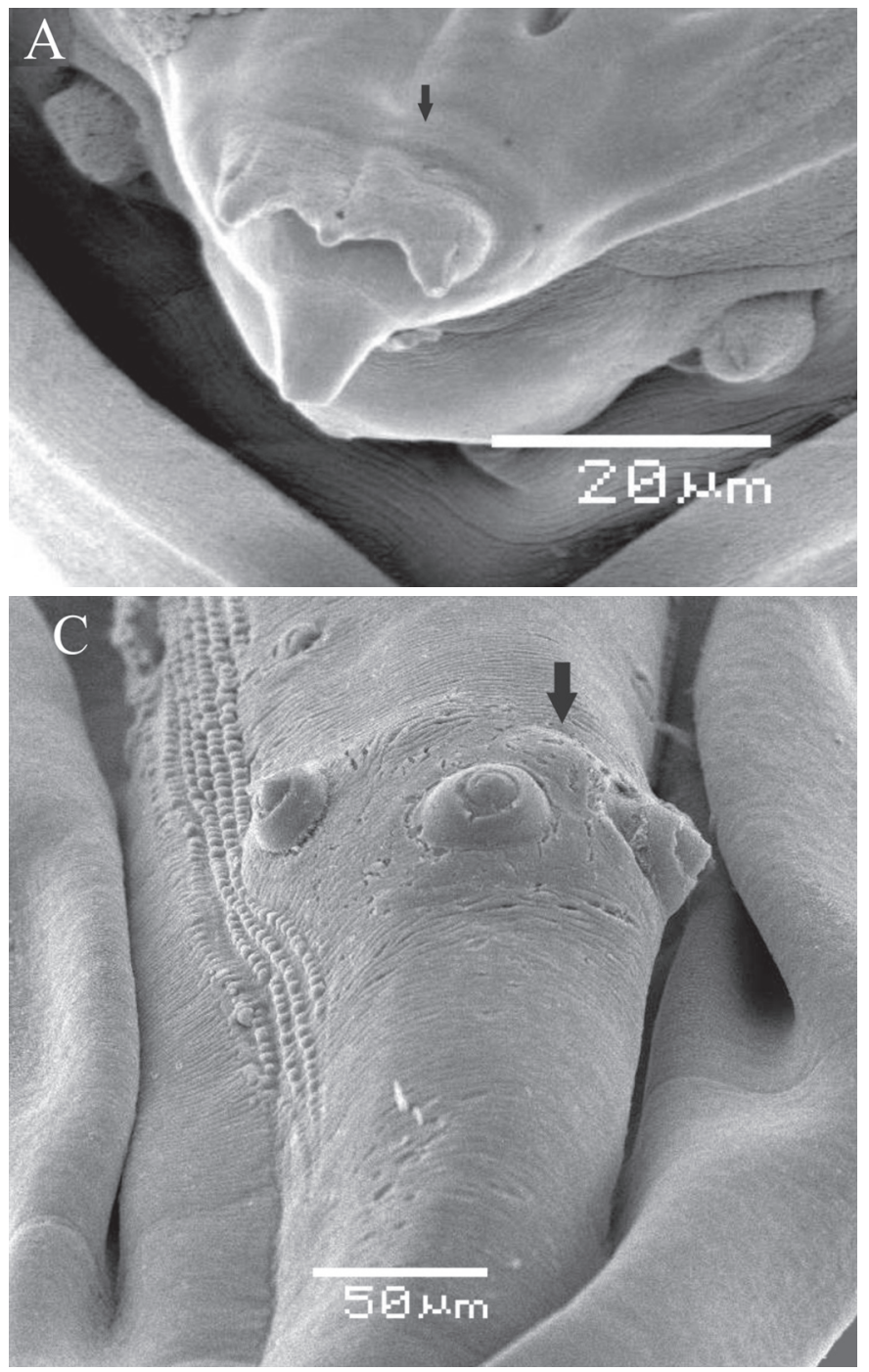
respectively. SEM revealed structures at the anterior end associated with tripartite teeth, such as pores, groove and the crescent fold on the inner side of lips (Fig.1A). At the posterior end of males, there was broad truncated caudal papilla on the tail (Fig.1B,C).

The lesions in the opossum were found are compatible with granulomatous inflammation, ulcers and fibrosis at the point of attachment.

\section{DISCUSSION}

Infection by Turgida turgida in species belonging to the genus Didelphis is characterized by enterogastric symptoms that lead to perforation of the intestinal wall as well as intense diarrhea, pylorus occlusion, intestinal hemorrhaging and weight loss (Schell 1952). Intensive parasitism of $T$. turgida in $D$. marsupialis has been associated to chronic cachexia and anemia (Nettles et al. 1975). A large number of studies have been carried out in North and South America on gastric and intestinal helminthes in the species from genus Didelphis, mainly in $D$. aurita and $D$. virginiana, reporting the presence of $T$. turgida based on light microscopy observations (Travassos 1920, Gray \& Anderson 1982, Alden 1995, Vicente et al. 1997, Silva \& Costa 1999, Gomes et al. 2003, Richardson \& Campo 2005, Nichelason et al. 2008). However, according to Matey et al. (2001), the features that differentiate Turgida turgida from other physalopterid species are the presence of structures associated with the tripartite teeth, as papilla like structures, groove and pores, the crescent fold on the inner side of the lips, and the presence of the 22nd broad truncated caudal papilla on the male tail, observed using scanning electron microscopy.

The observed lesions could potentially lead to gastric perforation and sepsis (Nettles et al. 1975, Alden 1995). Nichelason et al. (2008) points to T. turgida as one of the species that has a potential to cause significant morbidity and mortality in opossums.

Studies have shown that opossums have synanthropic behavior, which is a condition seen in cities with recent urbanization and expansion processes (Brandão-Filho et al. 2003). Such is the case of Campo Grande, which is characterized by remnants of native forest favorable to the appearance of wild animals in the city, especially opossums, which are adaptable to diverse conditions. According to Silva \& Costa (1999), studies on nematodes in opossums are scarce and mainly restricted to $D$. marsupialis and $D$. virginiana. The present study is the first report of $T$. turgida in the white-bellied opossum, confirmed by SEM in the Neotropical Region, and the first report in an urban area in the state of Mato Grosso do Sul, Brazil.

The license to collect biological material was numbered SISBIO 13838-1/Instituto Brasileiro de Recursos Naturais Renováveis (IBAMA).

Acknowledgements.- Study was supported by Fundect (Proc.23/ 200.041/2008). The authors are grateful to Dr. Angela Delben from
DFI/UFMS for helping with the SEM imaging and Namor Zimmermman for his assistance during the necropsy.

\section{REFERENCES}

Alden K.J. 1995. Helminths of the opossum, Didelphis virginiana, in Southern Illinois, with a compilation of all helminths reported from this host in North America. J. Helminthol. Soc. Washington 62:197-208.

Aléssio F.M., Pontes A.R.M. \& Silva V.L. 2005. Feeding by Didelphis albiventris on tree gum in the northeastern Atlantic forest of Brazil. Mastozool. Neotrop.12:37-52.

Anderson R.C. 2000. Nematode parasites of vertebrates: Their development and transmission. $2^{\text {nd }}$ ed. CAB Publishing, London. 672p.

Brandão-Filho S.P., Brito M.E., Carvalho F.G., Ishigawa E.A., Cupolillo E., Floeter-Winter L. \& Shaw J.J. 2003. Wild and synanthropic hosts of Leishmania (Viannia) braziliensis in the endemic cutaneous leishmaniasis locality of Amaraji, Pernambuco state, Brazil. Trans. R. Soc. Trop. Med. Hyg. 97:291-296.

Cáceres N.C. 2000. Food habits and seed dispersal by the Whiteeared opossum, Didelphis albiventris, in Southern Brazil. Stud. Neotrop. Fauna. Environ. 37:97-104.

Gomes D.C., Cruz R.P., Vicente J.J. \& Pinto R.M. 2003. Nematode parasites of marsupials and small rodents from Brazilian Atlantic Forest in the State of Rio de Janeiro, Brazil. Revta Bras. Zool. 20:699707.

Gray J.B. \& Anderson R.C. 1982. Development of Turgida turgida (Rudolphi, 1819) (Nematoda: Physalopteroidea) in the opossum (Didelphis virginiana). Can. J. Zool. 60:1265-1274.

Levine N.D. 1980. Nematode parasite of domestic animals and man. Burgess Publ. Co., Mineapolis. 477p.

Matey V.E., Kuperman B.I. \& Kinsella J.M. 2001. Scanning electron microscopy of Turgida turgida (Nematoda: Spiruroidea), parasite of the Virginia opossum, Didelphis virginiana, from Southern California. J. Parasitol. 87:1199-1202.

Nettles V.F., Prestwood A.K. \& Davidson W.R. 1975. Severe Parasitism in an opossum. J. Wildl. Dis. 11:419-420.

Nichelason A.E., Rejmanek D., Dabritz H.A., Melli A.C., Miller M. \& Conrad P.A. 2008. Evaluation of Cruzia americana, Turgida turgida, Didelphostrongylus hayesi infection in the Virginia opossum (Didelphis virginiana) and risk factors along the California cost. J. Parasitol. 94:1166-1168.

Richardson D.J. \& Campo J.D. 2005. Gastrointestinal helminths of the Virginia opossum (Didelphis virginiana) in South-Central Connecticut, USA. Comp. Parasitol. 72:183-185.

Schell S.C. 1952. Studies on the life cycle of Physaloptera hispida Schell (Nematoda: Spiruroidea) a parasite of the cotton rat (Sigmodon hispidus litioralis Chapman). J. Parasitol. 38:462-472.

Silva M.G.Q. \& Costa H.M.A. 1999. Helminths of white-bellied opossum from Brazil. J. Wildl. Dis. 35:371-374.

Travassos L. 1920. Contribuições para o conhecimento da fauna helmintológica brasileira. X. Sobre as espécies do gênero Turgida. Mem. Inst. Oswaldo Cruz 12:73-77.

Vicente J.J., Rodrigues H.O., Gomes D.C. \& Pinto R.M. 1997. Nematóides do Brasil. Parte V. Nematóides de mamíferos. Revta Bras. Zool. 14:1-452.

Widmer E.A. 1970. Development of third-stage Physaloptera larvae from Crotalus viridis Rafinesque, 1818 in cats with notes on pathology of the larvae in the reptile. (Nematoda, Spiruroidea). J. Wildl. Dis.6:8993.

Zago Filho H. 1959. Contribuição para o conhecimento do ciclo evolutivo da Turgida turgida (Rud. 1819), Travassos, 1920 (Nematoda: Spiruroidea). Arq. Zool. Est. São Paulo 11:99-120. 